\title{
Estimation of Rainfall-Runoff Relationship and Correlation of Runoff with Infiltration Capacity and Temperature Over East Singhbhum District of Jharkhand
}

\author{
Radhika Kumari, Mohit Mayoor, Somnath Mahapatra, P.K. Parhi, H.P. Singh
}

\begin{abstract}
In meteorology, Precipitation is any product of the condensation of atmospheric water vapor that falls under the gravity, the rainfall being the principal form of precipitation in India. Rainfall is the most important meteorological parameter for hydrology, as it controls the other processes such as infiltration, runoff, detention storage, and evapotranspiration. When precipitation falls over a catchment area, these processes have to be satisfied before precipitation water becomes runoff. Infiltration is the vertically downward flow of rainfall into ground/underground through percolation inside the soil surface and depends on soil-type, porosity, and permeability. Runoff is the flow of rainwater over the land surface that happens when there is an excess of precipitation over an area. Runoff is produced when the rainwater exceeds the infiltration capacity of the soil. The most important relationships for any watershed are the relationship between rainfall and runoff. This relationship depends on some factors such as characteristics of rainfall, runoff, and infiltration. Though the abovementioned factors have a major impact on the volume of runoff, a consistent correlation between rainfall-runoff enables us to increase more confidence in sufficient time for the formulation of appropriate decision making for the local authority. The present research work was undertaken to analyze the correlation between annual rainfall and annual runoff for the years 1901-2018 over Jamshedpur of East Singhbhum district, Jharkhand. Further in this study, the correlation between infiltration and annual runoff was analyzed over the same area and the same data period. Correlation between temperature and annual runoff was also found. Through the graphical analysis, it was found that the value of annual rainfall and runoff are strongly correlated.As the value of the Pearson correlation coefficient $(r)$ is almost equal to +1 which is a nearly perfect positive correlation, signifies that both variables move in the same direction. It also signifies that the two variables being compared have a perfect positive relationship; that means these two are strongly related. Through the study, it was also found that the infiltration and runoff are largely correlated. There was practically no correlation found between the values of temperature and runoff over the years.
\end{abstract}

Keywords: Infiltration, Runoff, Rainfall, Temperature

Revised Manuscript Received on December 30, 2019.

* Correspondence Author

Radhika Kumari, PG student, DWEM, Central University of Jharkhand, Ranchi, India.

MohitMayoor*, Assistant professor, DWEM, Central University of Jharkhand, Ranchi, India.

Somnath Mahapatra, Scientist-E, Indian Institute of Tropical Meteorology, Pune, India.

P.K. Parhi, Assistant professor, DWEM, Central University of Jharkhand, Ranchi, India.

H.P. Singh, Professor, DWEM, Central University of Jharkhand, Ranchi, India.

(c) The Authors. Published by Blue Eyes Intelligence Engineering and Sciences Publication (BEIESP). This is an open access article under the CC BY-NC-ND license (http://creativecommons.org/licenses/by-nc-nd/4.0/)

\section{INRODUCTION}

In meteorology, Precipitation is any product of the condensation of atmospheric water vapor that falls due to the effect of gravity. Precipitation occurs mainly in form of rainfall, snowfall, hail, frost, and dew. Rainfall is the principal form of precipitation in India. When precipitation falls over a catchment area, processes like infiltration, evapotranspiration, detention storage and initial losses have to be satisfied before precipitation water becomes runoff. Infiltration is the flow of rainfall to ground through the soil surface ${ }^{[2]}$. Runoff is the flow of rainwater over the land surface that happens when there is an excess of precipitation over an area. Singh and Purty (2016) did a rainfall-runoff analysis of East Singhbhum district over the time course of 2001 -2013 and found that the role of climatic elements such as temperature, rainfall, and runoff in this district is quite concrete [9]. Ghosh (2011) did a study of Quantitative and Spatial Analysis of Fluvial Erosion in relation to Morphometric Attributes of Sarujharna Basin over east Singhbhum district with an objective of Estimation of primary erosion process, i.e. surface runoff [5]. Along with these rainfall characteristics, there are also a number of precise factors on the event and volume of runoff as a direct effect (Pradhan et al. 2010). The relationship of rainfallrunoff is one of the most used procedures in hydrology. Different methods have been developed by different researchers for simulation of the rainfall-runoff process. Tandon and Nimbalkar (2014) have developed a relationship between runoff and rainfall and validated by using a statistical model [11]. This process is similar to those in rural areas but they generally occur at smaller time and space of urban areas than in rural areas (Delleur, 2003). ValdesandIturbe (1979) did a study "On the Influence of the Spatial Distribution of Rainfall on Storm Runoff" which was done to assess the importance of precipitation accuracy on the rainfall-runoff modeling of a small catchment [12]. The amount of interflow depends on the geological conditions of any catchment (Subramanya, 2009) provide a basic idea of runoff generation in relation to climate conditions (rainfall and infiltration) [10].Therefore, the main objectives of this paper are to study the correlation between infiltration, rainfall with runoff and their relationship. Rainfall is one of the major elements of the hydrologic cycle and the primary source of runoff (Beven, 2001b). 


\section{Estimation of Rainfall-Runoff Relationship and Correlation of Runoff with Infiltration Capacity and Temperature Over East Singhbhum District of Jharkhand}

In this fast-growing world rapid increase in cutting down trees and setting up of the industries has attracted urbanization. Singhbhum derives its name from "the land of lions". Indigenous habitat is debasing because of the undesirable impact of urbanization and population. The result can be seen in the form of increasing temperature. Due to a rise in temperature, there is variability in rainfall. There is an overdependence on paddy even on unsuitable land where soil fertility status is not so bad but water retention capacity is quite poor. Results can also be seen in the form of dying of theSubarnarekha River which serves as the main source of the river system. The present study aims to estimate the rainfall-runoff relationship in east Singhbhum district, Jharkhand, India. Under this study, the relationship between climatic parameters of the East Singhbhum district was analyzed by compiling the rainfall data from 1901 to 2018 annually to extract the runoff data. Some of the statistical analysis methods to study therelationship between climatic elements (rainfall, temperature, and infiltration) with runoff have been used.

\section{MATERIALS AND METHODS}

\section{A. Description of the study area}

East Singhbhum district is situated at the extreme corner of the southwest of Jharkhand having Longitudinal Extent of $86^{\circ} 04^{\prime}-86^{\circ} 54^{\prime} \mathrm{E}$ and Latitudinal Extent of $22^{\circ} 12-23^{\circ}$ 01 'N. It falls under the survey of India topo sheet No. 73 $\mathrm{J} / 01-03, \mathrm{~J} / 05-12 ; \mathrm{J} / 14-16$.
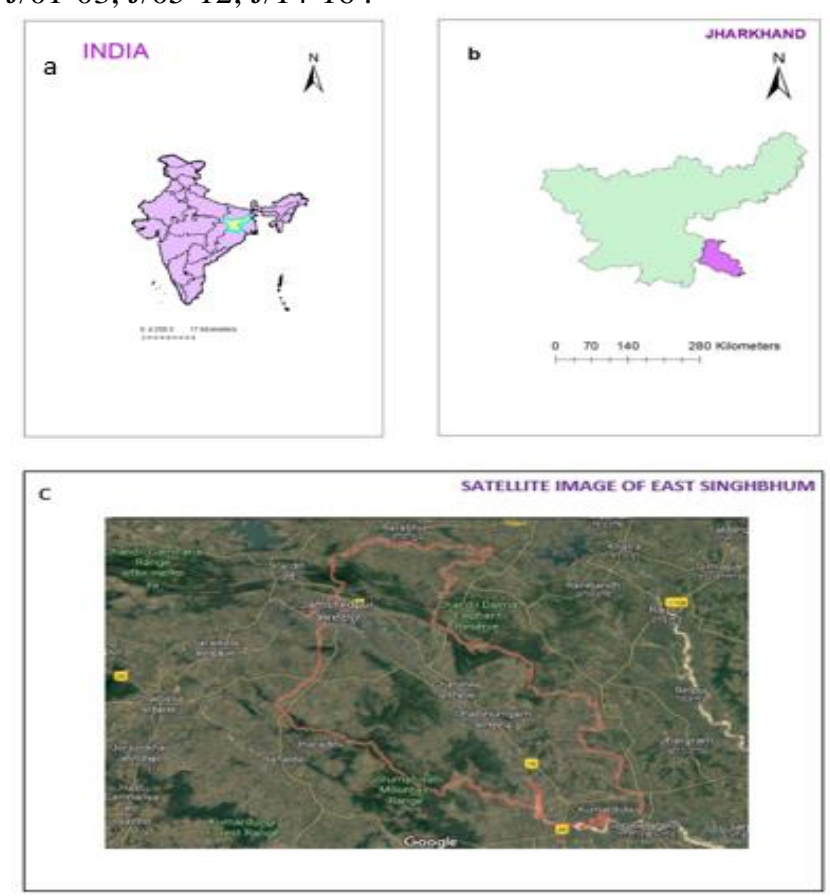

It has a total geographical area of 3533 Sq.Km which forms about $2.03 \%$ of the whole state. The district headquarter is at Jamshedpur. The Climate of the district is humid to sub-humid tropical having an average rainfall of 1200 to $1400 \mathrm{~mm}$. The area of East Singhbhum district comes under the path of southwest monsoon as a result of this it sometimes receives heavy rainfall from July to September. Deciduous type of forests is found in which Sal, Gamhar, Mahua, Palash, Bamboo, Shrubs and grass are the main vegetation. The district present covers $33 \%$ of its total area as a forest area. East Singhbhum district is mainly rocky. Soil texture varies from zone to zone. The nature of the soil is acidic lateritic and red soil (morum). Soil fertility position isn't so poor quality however water retention ability of soil is poor. Major rivers found in the district are Subarnarekha and Kharkai. Varied landforms like high hill ranges, eroded valleys, and undulating land are found in this district. East Singhbhum has a leading position in Jharkhand from the industrial growth and mining quarrying point of view.

\section{B. Data used}

To establish a correlation between Runoff and Infiltration with Rainfall and Runoff with temperature, monthly rainfall data of East Singhbhum from 1901-2018 and monthly mean temperature from 1901-2009 was used and it was downloaded from https://www.indiawaterportal.org/met_data/ for the years 1901 -2002 and from 2003-2018 for Rainfall and 2003-2009 from http://dsp.imdpune.gov.in/.The data used was taken from two IMD stations of East Singhbhum which are 42798 (JAMSHEDPUR) and 42799 (JAMSHEDPUR A).

\section{Methodology}

Method for Runoff- Infiltration Relationship:

The infiltration rate is the average rainfall above which the rainfall volume is equal to the runoff volume. The $\phi_{-}$index is a derivative of rainfall hyetograph with the resulting runoff volume. The initial loss is also considered as infiltration. The $\phi$ value can be found by treating it as a constant infiltration capacity. If the rainfall intensity is less than $\phi$, then the infiltration rate is equal to the rainfall intensity, and if the rainfall intensity is larger than ${ }^{\phi}$ the difference between the rainfall and infiltration in an interval of time represents the runoff volume. Based on rainfall and runoff correlation, the following relationship has been given by the (CWC, 1973) for the estimation of $\phi_{\text {-Index }}$

$R=\alpha \times I^{1.2}$

$\phi=\frac{I-R}{24}$

Where $\mathrm{R}=$ runoff in $\mathrm{cm}$

$\mathrm{I}=$ rainfall intensity from $24-\mathrm{h}(\mathrm{cm} / \mathrm{h})$

And $\alpha=$ coefficient which depends upon the soil type as indicated in Table I.

Table I: Variation of coefficient $\alpha$ according to CWC (1973)

\begin{tabular}{|l|l|l|}
\hline $\begin{array}{l}\text { Sl. } \\
\text { No. }\end{array}$ & Type Of Soil & $\boldsymbol{\alpha}$-coefficient \\
\hline $\mathbf{1}$ & Sandy soil and loam & 0.17 to 0.25 \\
\hline $\mathbf{2}$ & $\begin{array}{l}\text { Coastal alluvium and silty } \\
\text { loam }\end{array}$ & 0.25 to 0.34 \\
\hline $\mathbf{3}$ & $\begin{array}{l}\text { Red soils, clayey loam, grey } \\
\text { and brown alluvium }\end{array}$ & 0.42 \\
\hline $\mathbf{4}$ & Black-cotton and clayey soils & 0.42 to 0.46 \\
\hline $\mathbf{5}$ & Hilly soils & 0.46 to 0.50 \\
\hline
\end{tabular}

East Singhbhum comes under the first category, i.e., the soil type of East Singhbhum is Sandy soil and loam. Hence, for further studies, we will $\alpha$-coefficient value between 0.17 and 0.25 . 
Method for annual rainfall-runoff relationship:

This method (or formula) is adopted by Subramanya (2008) for the formulation of the linear regression line, it is a line adopted between $\mathrm{R}$ and $\mathrm{P}$ to show the result of correlation coefficient whose result is considered as nearer to unity which is known to be the good result [10].

The equations for the straight-line regression between runoff $\mathrm{R}$ and rainfall $\mathrm{P}$ is given as follows:

$R=a P+b$

$a=\frac{\mathrm{N}\left(\sum P R\right)-\left(\sum P\right) \times\left(\sum R\right)}{\mathrm{N}\left(\sum P^{2}\right)-\left(\left(\sum R\right)^{2}\right)}$

$b=\frac{\left(\sum R\right)-a\left(\sum P\right)}{N}$

$r=\frac{N\left(\sum P R\right)-\left(\sum P\right) \times\left(\sum R\right)}{\sqrt{\left(\left(N\left(\sum P^{2}\right)-\left(\sum P\right)^{2}\right) \times\left(N\left(\sum R^{2}\right)-\left(\sum R\right)^{2}\right)\right)}}$

Here,

$\mathrm{R}=$ Runoff

$\mathrm{P}=$ Rainfall

$\mathrm{N}=$ number of observation of sets $\mathrm{R}$ and $\mathrm{P}$

$\mathrm{r}=$ Co-efficient of correlation

The value of $\mathrm{r}$ lies between 0 and 1 as $\mathrm{R}$ can have only a positive correlation with $\mathrm{P}$. The value of $0.6<\mathrm{r}<1$ indicates a good correlation.

It should be noted that the value of $r>=0$.

\section{RESULTS AND DISCUSSIONS}

Estimation of runoff from rainfall intensity: Values for a (co-efficient) were taken as 0.17 from 19011914, 0.18 from 1915-1928, 0.19 from 1929-1943, 0.20 from 1944-1958, 0.21 from 1959-1973, 0.22 from 1974$1988,0.23$ from 1989-2003, and 0.24 from 2004-2018. The maximum value for the annual rainfall was found to be 17.8892, whereas the minimum value was 5.1432. From this estimation, the maximum value for the annual runoff was found to be 7.643977, whereas the minimum value was found to be 1.70913 .

\section{A. To establish a correlation between annual infiltration and annual runoff of East Singhbhum district (1901-2018)}

The maximum value for annual rainfall was found to be 17.8892, whereas, the minimum value was 5.1432. The maximum value for annual runoff was 7.643977 , whereas, the minimum value was found to be 5.1432. The maximum value found annual infiltration was found to be 0.441444 , whereas, the minimum value was 0.14271 .

From figure 4.1, it can be noted that the square of the correlation between the infiltration rate and runoff is 0.4792 . Now, $r^{2}=0.4792$

Therefore, $\mathrm{r}=0.6922$

Calculation of annual rainfall-runoff (1901-2018):

From the data table, it was seen that:

$\sum P=1575.706$,

$\sum R=868.611$

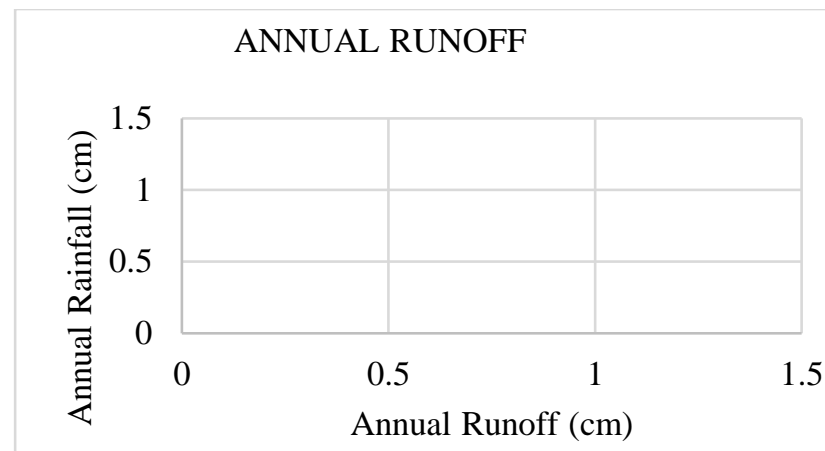

Fig. 4.1. Annual rainfall-runoff relationship of the study area (1901-2018)

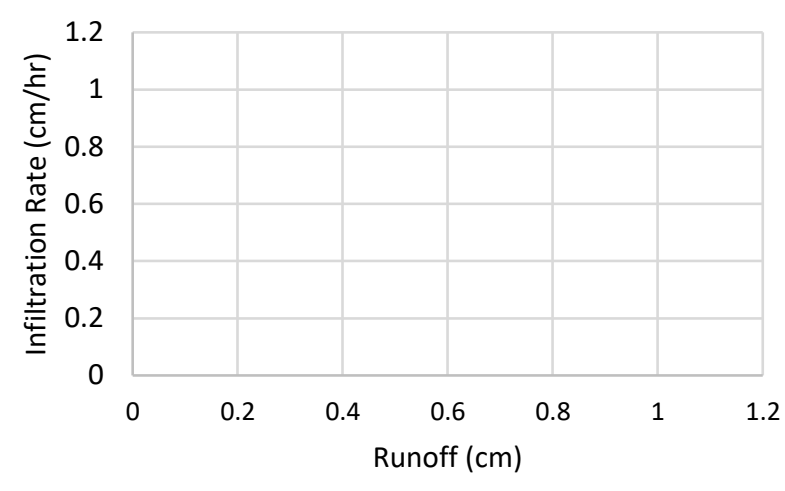

Fig. 4.2. Correlation between runoff and infiltration rate (1901-2018)

$\sum P^{2}=21736.283, \sum R^{2}=6884.055$

$\sum P R=12129.85$, number of years from $1901-2018, \mathrm{n}=118$

Thus, from equations (3), (4), (5) and (6),

$\mathrm{A}=0.0346$

$\mathrm{b}=68.99$

$\mathrm{R}=0.0346 \mathrm{p}+68.99$

Hence, coefficient of correlation, $r=0.953$.

B. To establish a correlation between annual rainfall and annual runoff (1901 -2018)

As the value of $r$ is almost equal to +1 which is a positive correlation, it signifies that both variables move in the same direction. It also signifies that these two variables have a perfect positive relationship; that means annual rainfall and annual runoff are strongly related.

The closer the value of $r$ is to +1 , the stronger the linear relationship. Positive values indicate a relationship between rainfall and runoff such that as the rainfall increases, runoff also increases. As the value of $r$ is nearer to +1 the correlation is saidto be good, figure. 3.2 represents the data points and the best fit straight line. Using the average annual rainfall along with the annual runoff scatter diagram is drawn. The rainfall-runoff relationship for East Singhbhum district indicates a good correlation between both properties with $r=0.953$. The linear regression is presented in figure of rainfall-runoff relationship. As we can expect a direct relationship between annual rainfall and runoff of the district. 


\section{Estimation of Rainfall-Runoff Relationship and Correlation of Runoff with Infiltration Capacity and Temperature Over East Singhbhum District of Jharkhand}

If the coordinates of the annual rainfall and runoff can be plotted in a coordinate system, parts of them can be fitted to a line or curve. Figure 4.3 shows the relationship between annual rainfall $(\mathrm{cm})$ and annual runoff $(\mathrm{cm})$ for East Singhbhum district. From the slope of the line which is 0.0346, a mathematical relationship between rainfall and runoff can be achieved.

Graphically, the equation was found to be:

$\mathrm{Y}=0.7637 \mathrm{X}-28.368$

$\mathrm{R}^{2}=0.8272$

Hence, $r=0.9095$

The amount of rainfall and runoff can also be shown in the form of a line graph as in Figure 4.3.From Figure 4.3 it can be seen that the values of rainfall and runoff are largely correlated. Over the years, the crests and troughs in rainfall data are impacting the runoff data to act similarly.From Figure 4.4, it can be seen that there is an increasing trend in runoff over the years with a sudden increase in the year 2006. With a slope of 0.3227 , the graph represents that the maximum runoff was in the year 2017.As per the analysis, the method adopted for the annual rainfall-runoff relationship for the formulation of the linear regression line is a line adopted between $r$ and $p$ to show the result of the correlation coefficient whose result is considered as nearer to unity which is known to be a good result. For accurate results, the sophisticated methods are adopted for the synthetic

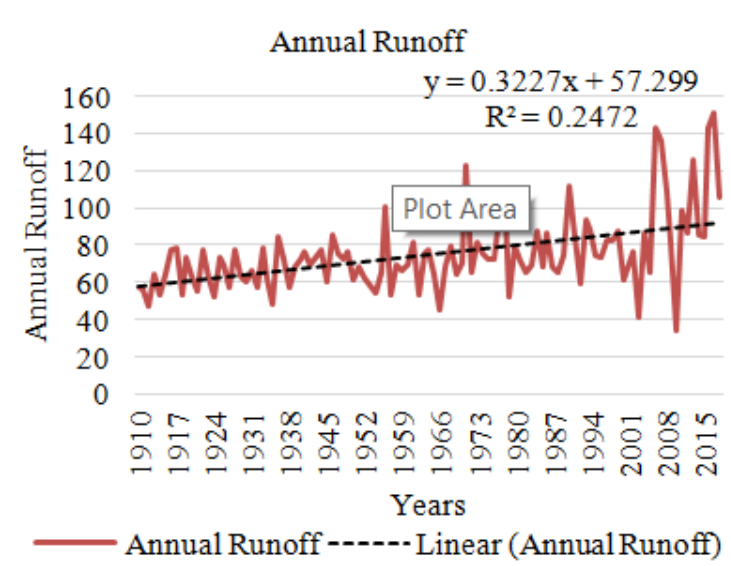

Fig. 4.3. Amount of annual rainfall and runoff data in the study area

Fig. 4.4. Representation of annual runoff in the study area generation of runoff data. Many improvements have been attempted for the above basic rainfall-runoff correlation antecedent rainfall influences the initial soil moisture and hence the infiltration rate at the start of the rainstorm.

\section{To establish a correlation between temperature and runoff (1901-2006)}

As it can be seen from the above graph, there is no significant correlation between the values of temperature and runoff over the years. This suggests that the insignificant temperature variation over East Singhbhum has not affected its runoff in any manner.

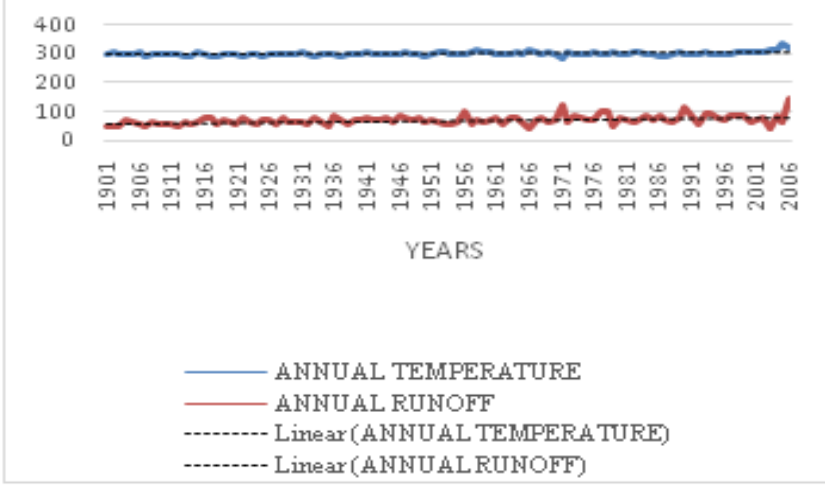

Fig. 4.5. Time series graph of annual temperature and annual runoff (1901-2006)

\section{SUMMARY AND CONCLUSIONS}

This section describes the overall analysis of the relationship of annual rainfall, annual infiltration, and annual temperature with annual runoff over East Singhbhum, Jharkhand. Regarding this approach, monthly rainfall data had been arranged from India Water Portal right from the year 1901-2010 except for the year 2003 and the years 2011 to 2018 where monthly mean rainfall was arranged from the data supply portal of Indian Meteorological Department, Pune. For Temperature, data was taken from the year 1901 - 2006. The relationship between rainfall and runoff gives an overall insight into how the annual runoff changes with variability in rainfall over East Singhbhum, Jharkhand. Further in the study, the relationship between infiltration and runoff and runoff and temperature is established. These have been depicted in the project through the graph plots and tables. Through the graph analysis, the value of annual rainfall-runoff is strongly correlated. As the value of $\mathrm{r}$ is equal to +1 which is a positive correlation, signifies that both variables move in the same direction. It also signifies that the two variables being compared have a perfect positive relationship; that means these two are strongly related. Through the study, it was also found that the infiltration and runoff are largely correlated. Although, there is no correlation between the values of temperature and runoff over the years.

\section{REFERENCES}

1. Chaubey,Haan, C.T., Grunwald,S. and Salisbury, J.M. 1999 Uncertainty in the model parameters due to spatial variability of rainfall, Journal of Hydrology, 220(1-2):48-61.

2. Chiew, F.H.S,Stewardson, M.J. and .McMahon, T.A. 1993 Comparison of six rainfall-runoff modelling approaches, Journal of Hydrology, 147(1-4):1-36.

3. Daksh, K., Kumari. V., Kumari, A., Mayoor, M., Singh, H.P. and Mahapatra, S. (2018), Drought Risk Assessment in the Vidarbha Region of Maharashtra India Using Standardized Precipitation Index, International Journal of Innovative Knowledge Concepts, Volume 6, Issue 10, DOI:11.25835/IJIK- 277

4. Faurès,J.M., Goodrich, D.C.,Woolhiser,D.C. and Sorooshian, S. 1995 Impact of small-scale spatial rainfall variability on runoff modeling,Journal of Hydrology,173(1-4):309-326.

5. Ghosh, S. 2011 Quantitative and Spatial Analysis of Fluvial Erosion in relation to Morphometric Attributes of Sarujharna Basin, East Singhbhum, Jharkhand, International journal of Geomatics and Geosciences, 2(1): 71-90. 
6. Kumari, A., Mayoor, M., Mahapatra, S., Singh, H.P. and Parhi, P.K., (2018), Flood Risk Monitoring of Koshi River Basin in North Plains of Bihar State of India, Using Standardized Precipitation Index, International Journal of Advance and Innovative Research, Indian Academicians and Researchers Association, Volume 5 Issue 3(I), DOI: 10.13140/RG.2.2.29919.71846.

7. Mayoor, M.,Kumari, A.,Mahapatra, S., Parhi, P. K. and Singh, H. P. (2018), Comparison of Four Precipitation Based Drought Indices in Marathwada Region of Maharashtra India, International Journal of Advance and Innovative Research, Indian Academicians and Researchers Association, Volume 5 Issue 4(X), DOI:10.13140/RG.2.2.15707.41768.

8. Pradhan, R., Pradhan, M.P., Ghose, M. K. Agarwal, V. S and Agarwal, S. 2010 Estimation of RainfallRunoff using Remote Sensing and GIS in and around Singtam, East Sikkim, International Journal of Geomatics And Geosciences,1(3):466-476.

9. Singh, P.K. and Purty, P. 2016 Estimation of rainfall-runoff relationship in East Singhbhum district, Jharkhand, India, BEST:International Journal of Management, Information Technology and Engineering, 4(10):15-28.

10. Subramanya K. (2008); Engineering Hydrologyll, Publisher Tata McGraw Hill, 3rd edition, pp. 13-20.

11. Tandon P.N. and Nimbalkar P.T. 2014 Rainfall-runoff relationships using curve number method: a case study, International Journal of Advanced Engineering Research and Studies,4(1):73-77.

12. Valdes, J.B. and Iturbe 1979 On the Influence of the Spatial Distribution of Rainfall on Storm Runoff, Water resources research,15(2):321-328.

13. Vijayalakshmi, P. , Luv, P.K. and Soni, A.K. 2016 Rainwater Runoff Estimation using Empirical Formulae Computed in C Programming Software for Puriliya District of West Bengal, Indian Journal of Science and Technology, 9(4),

14. Data and information for East Singhbhum have been collected from the following links:

http://www.imdpune.gov.in/ndc new/Request.html

https://www.indiawaterportal.org/met_data/

https://www.indiawaterportal.org/datafinder

https://jamshedpur.nic.in/

http://www.crida.in/CP-

2012/statewiseplans/Jharkhand\%20(Pdf)/JKD5-East\%20Singhbhum30.11.12.pdf

http://east-singhbhum.kvk4.in/

http://dcmsme.gov.in/dips/Singhbhum\%20East.pdf

\section{AUTHORS PROFILE}

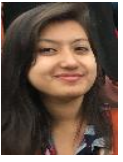

Radhika Kumari, PG student DWEM (M. Tech in Water Engineering and Management) from Central University of Jharkhand.

E-mail id: radhika.khatri.2897@gmail.com

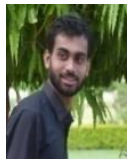

MohitMayoor, assistant professor in the department of water engineering and management.

M.Tech from DWEM (M. Tech in Water Engineering and Management) from Central University of Jharkhand.

Publications:

- $\quad$ Kumari, A., Mayoor, M., Mahapatra, S., Singh, H.P. and Parhi, P.K., (2018), Flood RiskMonitoring of Koshi River Basin in North Plains of Bihar State of India, UsingStandardized Precipitation Index, International Journal of Advance and InnovativeResearch, Indian Academicians and Researchers Association, Volume 5 Issue 3(I),DOI: 10.13140/RG.2.2.29919.71846.

- $\quad$ Daksh, K., Kumari., V., Kumari, A.,Mayoor, M., Singh, H.P. and Mahapatra, S. (2018),Drought Risk Assessment in the Vidarbha Region of Maharashtra India UsingStandardized Precipitation Index, International Journal of Innovative KnowledgeConcepts, Volume 6, Issue 10, DOI:11.25835/IJIK277.

- $\quad$ Mayoor, M.,Kumari, A.,Mahapatra, S., Parhi, P. K. and Singh, H. P. (2018), Comparisonof Four Precipitation Based Drought Indices in Marathwada Region of MaharashtraIndia, International Journal of Advance and Innovative Research, IndianAcademicians and Researchers Association, Volume 5 Issue 4(X),DOI:10.13140/RG.2.2.15707.41768. Publications: 29, December 2000, 319 - 332. 29, No. 1, 2005, $99-100$. nce 9 (1), January 2005, 29 - 40

E-mail id: mahap@tropmet.res.in

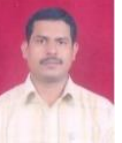

Publications: 10.3923/ijar.2017.115.122 No.:63571 UGC Journal Indexed No. : 63571 E-mail id: prabeer11@yahoo.co.in

SomnathMahapatraScientist-E, Monsoon Mission Division, Indian Institute of Tropical Meteorology.

- Mahapatra, S. and A. Bandyopadhyay, "Impact of digital filtering initialization on the performance of a semi-Lagrangian semi-implicit model over Indian region" Indian Journal of Radio \& Space Physics,

- Mahapatra, S. and A. Bandyopadhyay, Numerical Simulation of a thunderstorm event over an Ind ian station using a high resolution meso scale model", Vatavaran, 28, No. 1 \& 2, 2004, 38 - 51.

- Mahapatra, S., "Thunderstorm and our life cycle", Vatavaran,

- Bandyopadhyay, A. and S. Mahapatra, "Impact of recursive digital filtering initialization on forecast performa of a limited area mode over Indian region", Journal of Indian Geophysical Union,

PK Parhi, assistant professor in the department of Water Engineering and Management.

He has completed his PhD from IIT Roorkee.

- P. K. Parhi, (2017), Improving Wate Application Efficiency of Irrigation Borders Using Modified Water Front Advance-Time Relation, International Journal of Agricultural Research, Science Alert Publication, Vol 12:03, 115-122, eISSN: 2152-2553 pISSN: 1816-4897, DOI

- $\quad$ P.K. Parhi, (2018), Flood Management in Mahanadi Basin using HEC-RAS and Gumbel's Extreme Value Distribution, Journal of The Institution of Engineers (India): Series A, Springer Online First, http://www.springer.com/ home, ISSN 2250-2149, UGC Journal No:11114, DOI 10.1007/s40030-018-0317-4

- A, Kumari, S. Mahapatra, H.P. Singh, P.K. Parhi, (2018), "Flood Risk Monitoring of Koshi River Basin in North Plains of Bihar State of India, Using Standardized Precipitation Index", International Journal of Advance and Innovative Research, Volume 5, Issue 3 ( I ) : July - September, Indian Academicians and Researchers Association, ISSN: 2394-7780, UGC Indexed

- M. Mayoor, AnjaniKumari, S. Mahapatra, P, K. Parhi, H.P. Singh, (2018), "Comparison of Four Precipitation Based Drought Indices in Marathwada Region of Maharashtra, India”, International Journal of Advance and Innovative Research, Volume 5, Issue 4 ( $\mathrm{X}$ ) : October-December, Indian Academicians and Researchers Association, ISSN: 2394-7780,

- D. Kumar, V. K. Tripathi, P.K. Parhi, (2018), "Flood Flow Modelling and Embankment Protection of Mahanadi Rive Using HEC-RAS", i-manager's Journal on Future Engineering and Technology, i-manager's Publications, Vol. 13 - No. 4 • May - July, ISSN 0973-2632, UGC Indexed No.:6357

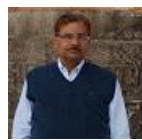

Publications:

- $\quad$ B.K. Maheshwari, H.P. Singh and S. Saran, (2013). Closure to Effects of Reinforcement on Liquefaction Resistance of Solan Sand. ASCE Journal of Geotechnical and Geoenvironmental Engineering, 139, 1633-1635.

- T. Muni, Y. Jeram, K. Padu, Y. Omo and H.P. Singh, (2014). Strength and Stiffness Response of Itanagar Soil Reinforced with ArecanutFiber.International Journal of Innovative Research in Science, Engineering and Technology, 3 (10), 16659-16667. 


\section{Temperature Over East Singhbhum District of Jharkhand}

- $\quad$ A. Kumari, M. Mayur, S. Mahapatra, H.P. Singh, and P.K. Parhi, (2018). Flood Risk Monitoring of Koshi River Basin in North Plains of Bihar State of India Using Standardized Precipitation Index. International Journal of Advance and Innovative Research, 5 (4), 21-30.

- M. Mayoor, A. Kumari, S. Mahapatra, P.K. Parhi and H.P. Singh, (2018).Comparison of Four Precipitation Based Drought Indices in Marathwada Region of Maharastra, India.International Journal of Advance and Innovative Research, 5 (4),60-70

- $\quad$ K. Daksh, V. Kumari, A. Kumari, M. Mayoor, H.P. Singh, and S. Mahapatra, (2018). Drought Risk Assessment in Vidarbha Region of Maharashtra, India Using Standardized Precipitation Index. International Journal of Innovative knowledge Concept, 6 (10), 13-23.E-mail id: singh.harendra121@gmail.com. 